\title{
Influence of Seed Fortification on Growth and Seed Yield in Blackgram (Vigna mungo L.) cv. Rashmi
}

\author{
Yogesh Thane $^{1}$, K. Vishwanath ${ }^{1}$, P. Mahadevu ${ }^{1}$, K. Shruthi ${ }^{1 *}$ and J. B. Maruthi ${ }^{2}$ \\ ${ }^{1}$ Department of Seed Science and Technology, University of Agricultural Science, GKVK, \\ Bangalore, India \\ ${ }^{2}$ Department of Seed Science and Technology, University of Agricultural Science, \\ Mandya, India
}

*Corresponding author

\section{A B S T R A C T}

\begin{tabular}{|l|}
\hline Ke y w o r d s \\
$\begin{array}{l}\text { Seed fortification, } \\
\text { Growth and seed } \\
\text { yield, Blackgram }\end{array}$ \\
\hline Article Info \\
\hline $\begin{array}{l}\text { Accepted: } \\
\text { 08 January } 2020 \\
\text { Available Online: } \\
\text { 10 February } 2020\end{array}$ \\
\hline
\end{tabular}

\section{Introduction}

Black gram [Vigna mungo L.) is one of the most important pulse crops among the various grain legumes in India. According to Vavilov (1951) it is native to India, belong to the family Leguminaceae. It is a rich protein food, contains about $26 \%$ protein, $1.2 \%$ fat and $56.6 \%$ carbohydrates on dry weight basis and also rich source of calcium and iron. This crop is cultivated mostly on marginal lands in mono/ mixed cropping system without any fertilizers under rainfed conditions.
Field experiment was conducted during Rabi-2016 to study the effect of seed fortification on growth and seed yield in blackgram (Vigna mungoL.) cv. Rashmi, The experiment consisted of fourteen treatments which were replicated thrice in RCBD design. Experimental results indicated that micro and macronutrients mixture (mixture of Borax, $\mathrm{CaCl}_{2}, \mathrm{FeSO}_{4}, \mathrm{ZnSO}_{4}$, $\mathrm{MgSO}_{4}$, water soluble DAP- 12:61:0, Water soluble 19:19:19, water soluble 13:0:45)@1\% significantly increased growth attributes, seed yield and benefit cost ratio in black gram seed production over control. 
established. Soil and foliar applications are the most prevalent methods of nutrient addition. At the initial phases of seed germination, nutrients are mobilized from endosperm or cotyledon, while further phases required nutrients from soil or from some other means. At initial stages seedling can't absorb nutrient from soil. Nutrient seed treatments, which include seed fortification and seed coating or pelleting, are an attractive and easy alternative.

Seed fortification is a physiological method of impregnation of the needy substance into the seed through the imbibition phase and enriches the endogenous level of the needy bioactive substances that aids in improving the initial stamina of the seed that helps in improving the initial field stand and that of the final yield (Hegarty, 1970). In seed fortification, seeds are partially hydrated to allow metabolic events to occur without actual germination, and then re-dried (near to their original weight) to permit routine handling. Such seeds germinate faster than non-fortified seeds.

\section{Materials and Methods}

The field experiment was conducted during Rabi- 2016 at Zonal Agricultural Research Station, V. C. Farm, Mandya. The experiment was laid out in Randomized Complete Block Design (RCBD) with 14 treatments and three replications using popular variety Rashmi.

Treatments

$\mathrm{T}_{0}$ : Control (hydropriming),

$\mathrm{T}_{1}$ : $\operatorname{Borax}(1.0 \%)$,

$\mathrm{T}_{2}: \mathrm{CaCl}_{2}(1.0 \%)$,

$\mathrm{T}_{3}: \mathrm{FeSO}_{4}(1.0 \%)$,

$\mathrm{T}_{4}: \mathrm{ZnSO}_{4}(1.0 \%)$,

$\mathrm{T}_{5}: \mathrm{MgSO}_{4}(1.0 \%)$,

$\mathrm{T}_{6}$ : Water soluble DAP- 12:61:0 (1.0\%),

$\mathrm{T}_{7}$ : Water soluble 19:19:19 (1.0\%),

$\mathrm{T}_{8}$ : Water soluble 13:0:45 (1.0\%),
$\mathrm{T}_{9}$ : Micronutrient mixture $(0.5 \%)$,

$\mathrm{T}_{10}$ : Micronutrient mixture $(1.0 \%)$,

$\mathrm{T}_{11}$ : Macronutrient mixture $(0.5 \%)$,

$\mathrm{T}_{12}$ : Micro and Macronutrients mixture (0.5

$\%)$,

$\mathrm{T}_{13}$ : Micro and Macronutrients mixture (1.0 $\%)$.

The graded seeds were subjected to soaking in micro and macronutrients (Borax, $\mathrm{CaCl}_{2}$, $\mathrm{FeSO}_{4}, \mathrm{ZnSO}_{4}, \mathrm{MgSO}_{4}$, Water soluble DAP12:61:0, Water soluble 19:19:19, Water soluble 13:0:45) at one per cent and their combinations as micronutrient mixture (Borax $\mathrm{CaCl}_{2}, \mathrm{FeSO}_{4}, \mathrm{ZnSO}_{4}, \mathrm{MgSO}_{4} @ 0.5$ and 1 $\%$ ), macronutrient mixture (Water soluble DAP- 12:61:0, Water soluble 19:19:19, Water soluble 13:0:45@1\%) and combination of both micro and macronutrients at @0.5 and 1 $\%$ for 3 hours adopting the seed to solution ratio of $1: 3$. Then the seeds were shade dried for one day in lab condition to bring back to their original moisture content and used for sowing, keeping hydro primed seeds as control. Five plants per plot were selected randomly in the net plot area and tagged for recording growth and yield parameters. The results were analyzed statistically to draw suitable inference as per standard ANOVA technique as described by Gomez and Gomez (1984).

\section{Results and Discussion}

\section{Effect on growth attributes}

Significant differences were noticed on growth, seed yield and yield attributing characteristics of black gram among the seed fortification treatments. Seeds fortified with micro and macronutrient mixture @ $1 \%$ recorded higher plant height (27.07), number of branches per plant (4.57) and number of leaves (9.87) at harvest compared to rest of the treatments at harvest of recording observation (Table 1). 
Increase in plant height was possibly attributed to internodal elongation by cell division by enhanced carbohydrate metabolism and metabolic and physiological processes by plants (Ashour and Reda, 1972) and increased cell division. The micro and macro elements are involved in biosynthesis of plant harmones, indole acetic acid, auxin metabolism (Krishnasamy, 2003). The increase in number of leaves and branches might be due to better nutrient availability at early stage of plant might have ascribed to their pivotal role in several physiological and biochemical processes, viz., root development, photosynthesis, energy transfer reaction and symbiotic biological $\mathrm{N}$ fixation process (Rathinavel andDharmalingam, 1999).

\section{Effect on yield attributes and yield:}

A perusal of data (Table 1-2) revealed that yield attributes viz., number of pods plant ${ }^{-1}$ (17.03), number of pods cluster ${ }^{-1}$ (2.94), pod weight plant $^{-1}(5.66 \mathrm{~g})$, pod length $(5.08 \mathrm{~cm})$, number of seeds $\operatorname{pod}^{-1}(6.18)$, seed yield plant 1 (4.30 g), seed yield hectare ${ }^{-1}(13.14 \mathrm{q})$, graded seed yield $(12.11 \mathrm{q})$, shelling \% (86.11) increased significantly with the seed fortified with micro and macronutrient mixture @ $1 \%$ in black gram over control.

The increased seed yield attributes might be due to early emergence of fortified seeds resulted in increased number of leaves which increased supply nutrients to sink through translocation and accumulation of photosynthates in the economic sinks (Rathinavel and Dharmalingam, 1999) and enhanced vegetative growth and synergistic effect of use of micro and macronutrients involved in improvement in crop performance. The multi nutrients treatment improved the growth of the plant during early stages of the crop which increased the vigour and associated stronger root system, in turn derived the available soil moisture and nutrients enabling better growth, resulting in higher yield (Jagathambal, 1996).

Fig.1 Gross returns and net returns of black gram as influenced by seed fortification

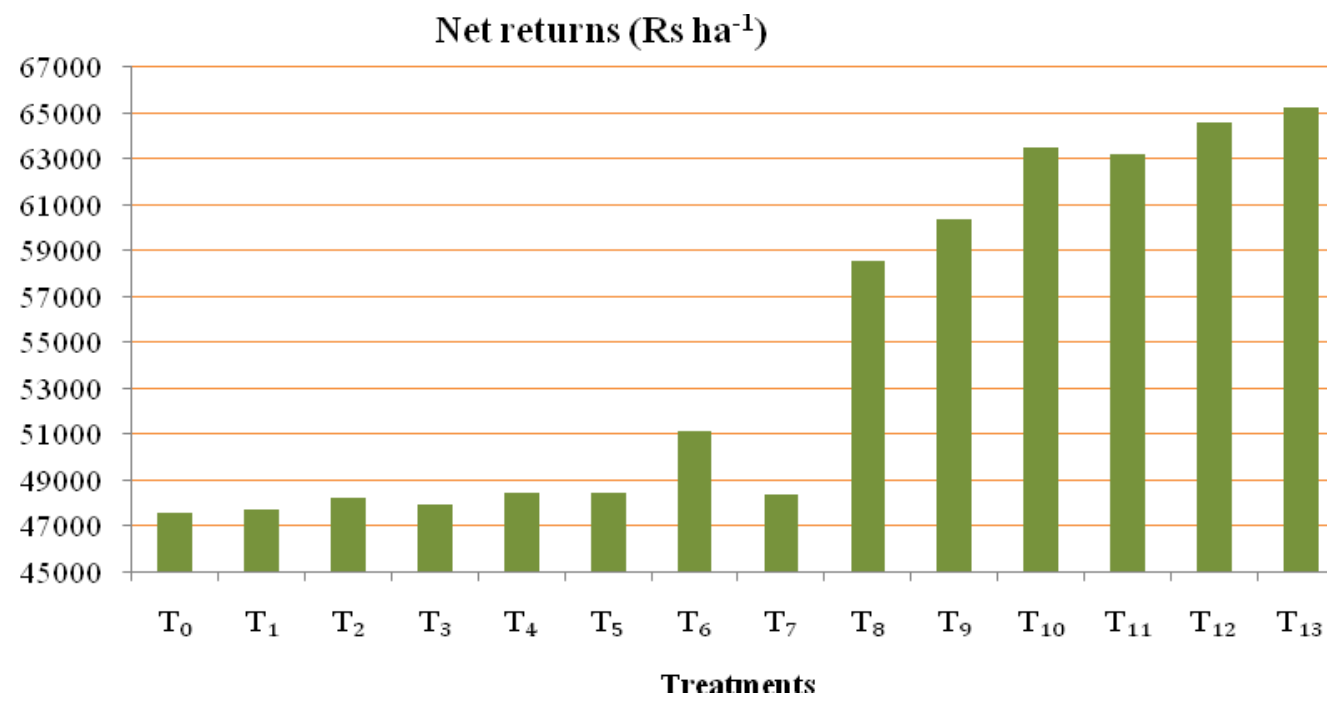


Table.1 Growth and yield parameters of black gram as influenced by seed fortification

\begin{tabular}{|c|c|c|c|c|c|c|c|c|}
\hline Treatments & $\begin{array}{c}\text { Plant } \\
\text { height } \\
(\mathrm{cm}) @ \\
\text { harvest }\end{array}$ & $\begin{array}{l}\text { Number } \\
\text { of leaves }\end{array}$ & $\begin{array}{l}\text { Number of } \\
\text { branches }\end{array}$ & $\begin{array}{l}\text { Number of } \\
\text { clusters/plant }\end{array}$ & $\begin{array}{l}\text { Number of } \\
\text { pods/plant }\end{array}$ & $\begin{array}{c}\text { Number of } \\
\text { pods/cluster }\end{array}$ & $\begin{array}{l}\text { Pod length } \\
\quad(\mathrm{cm})\end{array}$ & $\begin{array}{l}\text { Number of } \\
\text { seeds/pod }\end{array}$ \\
\hline $\mathbf{T}_{0}:$ Control & 20.07 & 7.13 & 3.59 & 4.30 & 13.03 & 1.88 & 4.00 & 4.96 \\
\hline$T_{1}: \operatorname{Borax}(1.0 \%)$ & 21.17 & 8.20 & 4.00 & 5.13 & 13.80 & 2.24 & 4.31 & 5.08 \\
\hline $\mathrm{T}_{2}: \mathrm{CaCl}_{2}(1.0 \%)$ & 21.80 & 8.33 & 4.07 & 5.27 & 13.87 & 2.35 & 4.37 & 5.13 \\
\hline $\mathrm{T}_{3}: \mathrm{FeSO}_{4}(1.0 \%)$ & 21.53 & 8.00 & 4.10 & 5.33 & 14.20 & 2.36 & 4.38 & 5.17 \\
\hline $\mathrm{T}_{4}: \mathrm{ZnSO}_{4}(1.0 \%)$ & 21.20 & 8.33 & 4.20 & 5.60 & 14.30 & 2.37 & 4.50 & 5.23 \\
\hline $\mathrm{T}_{5}: \mathrm{MgSO}_{4}(1.0 \%)$ & 21.40 & 8.13 & 4.27 & 5.80 & 14.43 & 2.41 & 4.50 & 5.32 \\
\hline$T_{6}:$ Water soluble DAP- 12:61:0 (1.0 \%) & 21.40 & 8.27 & 4.37 & 5.60 & 15.23 & 2.42 & 4.53 & 5.34 \\
\hline$T_{7}:$ Water soluble 19:19:19 (1.0 \%) & 21.73 & 8.07 & 4.33 & 5.87 & 14.73 & 2.49 & 4.57 & 5.39 \\
\hline $\mathrm{T}_{8}:$ Water soluble 13:0:45 (1.0 \%) & 22.03 & 7.80 & 4.37 & 5.73 & 14.97 & 2.55 & 4.63 & 5.54 \\
\hline $\mathrm{T}_{9}:$ Micronutrient mixture $(0.5 \%)$ & 22.00 & 8.07 & 4.23 & 6.33 & 15.20 & 2.60 & 4.68 & 5.59 \\
\hline$T_{10}:$ Micronutrient mixture $(1.0 \%)$ & 22.67 & 7.93 & 4.27 & 6.43 & 15.37 & 2.63 & 4.69 & 5.71 \\
\hline$T_{11}:$ Macronutrient mixture $(0.5 \%)$ & 24.53 & 8.60 & 4.40 & 6.50 & 15.53 & 2.66 & 4.77 & 5.73 \\
\hline$T_{12}:$ Micro and Macronutrients $(0.5 \%)$ & 25.50 & 9.47 & 4.53 & 6.70 & 16.53 & 2.69 & 5.01 & 6.02 \\
\hline$T_{13}:$ Micro and Macronutrients $(1.0 \%)$ & 27.07 & 9.87 & 4.57 & 6.97 & 17.03 & 2.94 & 5.08 & 6.18 \\
\hline Mean & 22.44 & 8.30 & 4.24 & 5.83 & 14.87 & 2.47 & 4.57 & 5.46 \\
\hline S.Em \pm & 1.30 & 0.45 & 0.20 & 0.43 & 0.81 & 0.17 & 0.19 & 0.25 \\
\hline C.D. $(P=0.05)$ & 3.77 & 1.31 & 0.58 & 1.25 & 2.34 & 0.49 & 0.55 & 0.71 \\
\hline C.V $(\%)$ & 10.02 & 9.43 & 8.21 & 12.73 & 9.38 & 11.73 & 7.15 & 7.80 \\
\hline
\end{tabular}


Table.2 Yield parameters, seed yield and economics of black gram seed production as influenced by seed fortification treatments

\begin{tabular}{|c|c|c|c|c|c|c|c|c|c|}
\hline Treatments & $\begin{array}{c}\text { Pod } \\
\text { weight } \\
\text { /plant }\end{array}$ & $\begin{array}{c}\text { Seed } \\
\text { yield/ } \\
\text { plant (g) }\end{array}$ & $\begin{array}{c}\text { Shelling } \\
(\%)\end{array}$ & $\begin{array}{c}\text { Seed } \\
\text { yield } \\
\text { (q/ha) }\end{array}$ & $\begin{array}{c}\text { Graded } \\
\text { seed yield } \\
\text { (q/ha) }\end{array}$ & $\begin{array}{c}\text { Cost of } \\
\text { cultivation } \\
\left(\text { Rs. ha }{ }^{-1}\right)\end{array}$ & $\begin{array}{c}\text { Gross } \\
\text { return } \\
\left(\text { Rs. } \text { ha }^{-1}\right)\end{array}$ & $\begin{array}{c}\text { Net } \\
\text { return } \\
\left(\begin{array}{c}\text { Rs. ha } \\
\mathbf{1}_{\text {) }}\end{array}\right.\end{array}$ & $\begin{array}{c}\text { B:C } \\
\text { Ratio }\end{array}$ \\
\hline $\mathbf{T}_{0}:$ Control & 4.11 & 3.62 & 51.51 & 11.07 & 10.04 & 40889 & 88352 & 47565 & 2.160 \\
\hline$T_{1}: \operatorname{Borax}(1.0 \%)$ & 4.44 & 3.63 & 64.82 & 11.10 & 10.08 & 40980 & 88704 & 47723 & 2.164 \\
\hline $\mathrm{T}_{2}: \mathrm{CaCl}_{2}(1.0 \%)$ & 4.51 & 3.65 & 65.54 & 11.16 & 10.14 & 40989 & 89232 & 48242 & 2.176 \\
\hline $\mathrm{T}_{3}: \mathrm{FeSO}_{4}(1.0 \%)$ & 4.57 & 3.64 & 66.08 & 11.12 & 10.10 & 40989 & 88880 & 47891 & 2.168 \\
\hline $\mathrm{T}_{4}: \mathrm{ZnSO}_{4}(1.0 \%)$ & 4.59 & 3.66 & 68.47 & 11.18 & 10.16 & 40986 & 89408 & 48422 & 2.180 \\
\hline $\mathrm{T}_{5}: \mathrm{MgSO}_{4}(1.0 \%)$ & 4.63 & 3.66 & 66.93 & 11.18 & 10.16 & 40991 & 89408 & 48416 & 2.181 \\
\hline$T_{6}:$ Water soluble DAP- 12:61:0 (1.0 \% ) & 4.64 & 3.76 & 70.04 & 11.50 & 10.47 & 40984 & 92136 & 51152 & 2.248 \\
\hline$T_{7}:$ Water soluble 19:19:19 (1.0 \%) & 4.70 & 3.66 & 70.46 & 11.18 & 10.16 & 41027 & 89408 & 48381 & 2.179 \\
\hline$T_{8}:$ Water soluble 13:0:45 (1.0 \%) & 4.74 & 4.04 & 73.67 & 12.33 & 11.31 & 40985 & 99528 & 58543 & 2.428 \\
\hline T9: Micronutrient mixture (0.5 \%) & 4.73 & 4.11 & 79.17 & 12.53 & 11.54 & 41174 & 101552 & 60378 & 2.466 \\
\hline$T_{10}:$ Micronutrient mixture $(1.0 \%)$ & 4.82 & 4.23 & 80.30 & 12.91 & 11.89 & 41140 & 104632 & 63491 & 2.543 \\
\hline$T_{11}$ : Macronutrient mixture (0.5\%) & 4.87 & 4.22 & 80.54 & 12.89 & 11.87 & 41233 & 104456 & 63222 & 2.533 \\
\hline$T_{12}:$ Micro and Macronutrients $(0.5 \%)$ & 5.41 & 4.27 & 81.34 & 13.06 & 12.03 & 41258 & 105864 & 64605 & 2.565 \\
\hline$T_{13}:$ Micro and Macronutrients $(1.0 \%)$ & 5.66 & 4.30 & 86.11 & 13.14 & 12.11 & 41323 & 106568 & 65245 & 2.578 \\
\hline Mean & 4.74 & 3.89 & 71.78 & 11.88 & 10.86 & - & - & - & - \\
\hline S.Em \pm & 0.23 & 0.19 & 5.05 & 0.59 & 0.59 & - & - & - & - \\
\hline C.D. $(P=0.05)$ & 0.68 & 0.56 & 14.68 & 1.72 & 1.71 & - & - & - & - \\
\hline C.V $(\%)$ & 8.49 & 8.58 & 12.18 & 8.61 & 9.39 & - & - & - & - \\
\hline
\end{tabular}


Micronutrients are constituent of several dehydrogenase enzymes and also an activator of other enzymes. The increased pod yield might also due to unaborted reproductive structures that could have resulted due to higher photosynthetic activity. As far as the increase in the seed yield per plant is concerned, the physio-chemical treatments could have triggered the biosynthesis of nucleic acids, proteins and the consequential enhancement of cell division, besides, the enhanced metabolic activity of the plants resulting on the increased uptake and more availability of nutrients which enhanced pod setting, pod formation and responsible for increased pod and grain yield of black gram (Poongothai and Chitdeshwari, 2003, Vanitha and Kathiravan, 2016, Suman, 2002).

\section{Economics of the treatments}

Significantly higher maximum net return (Rs. $65245 \mathrm{ha}^{-1}$ ) and $\mathrm{B}: \mathrm{C}$ ratio (2.58) was recorded with seed fortified with micro and macronutrient mixture @ 1\% over rest of the treatments and control (Table-2) which was followed by micro and macronutrient mixture (a) $0.5 \%$ (Rs 64605, 2.56). Significantly increased net return and benefit cost ratio could be explained on the basis of increased yield under the influence of sources of inorganic nutrients in the present investigation (Fig 1).

Thus the study revealed that seed fortification with 1 per cent micro and macronutrients mixture could be adopted as a pre-sowing seed treatment for Black gram seed production for enhanced seed yield, quality and net returns.

\section{References}

Ashour, N. I. and Reda, F., 1972.Effect of foliar application of some microelements on growth and some physio- chemical properties of sugarbeet growth in winter season.Curr. Sci., 41(4): 146147.

Gomez, K. A. and Gomez, A. A., 1984. Statistical procedures in agricultural research.John Wiley and sons, New York.pp. 680.

Hegarty, T. W., 1970. The possibilities of increasing field establishment by seed hardening. Hort. Res., 10: 59-64.

Jagathambal, R., 1996. Pre-sowing seed treatment to augment productivity of sorghum. Cv. CO-26. Madras Agric. J.,83: 585-590.

Krishnasamy, V., 2003.Seed pelleting principles and practices. ICAR Short Course on Seed Hardening and Pelleting Technologies for Rainfed/Garden Land Ecosystems: May 27 to June 5, Tamil Nadu Agricultural University., Coimbatore, pp. 96.

Poongothai, S. and Chitdeshwari, T., 2003. Response of blackgram to multimicronutrients.Madras Agric. J. 90: 442-443.

Rathinavel, K. and Dharmalingam, C., 1999. Effect of seed pelleting on elite seedling production in cotton cv. McV7 (Gossypiumhirsutum L.).Crop Res., 18(1): 137- 141.

Suman, N., 2002. Influence of seed pelleting on storability, crop growth, seed yield and quality in sunflower (Helianthus annuus L.) cv. Morden. M. Sc. (Agri.) Thesis, Uni. Agric. Sci., Dharwad.

Vanitha, C. and Kathiravan, M., 2016.Response of black gram (VignamungoL.) to seed biofortification and foliar nutrition intervention in relation to seed quality and yield potential.Int. J. Appl. and Natural Sci., 5(6): 69-78.

Vavilov, N. I., 1951. The Origin, Variation, Immunity and Breeding of Cultivated Plants. Chron. Bot. 13: 1-364. 


\section{How to cite this article:}

Yogesh Thane, K. Vishwanath, P. Mahadevu, K. Shruthi and Maruthi, J. B. 2020. Influence of Seed Fortification on Growth and Seed Yield in Blackgram (Vigna mungo L.) cv. Rashmi. Int.J.Curr.Microbiol.App.Sci. 9(02): 1144-1150. doi: https://doi.org/10.20546/ijcmas.2020.902.134 